\title{
Leveraging India: Global Interconnectedness and Locational Competitive Advantage
}

\author{
Farok J. Contractor • Vikas Kumar • \\ Charles Dhanaraj
}

(C) Springer-Verlag Berlin Heidelberg 2015

\begin{abstract}
This paper reviews India's place in the international economy by identifying areas of its comparative advantage, characteristics of the Indian market and institutional environment, capabilities of Indian companies as global players, India's human resource base and demographics, and industry and knowledge clusters which already are, or have the potential to become, globally competitive. Drawbacks, such as labor laws, inadequate infrastructure, and the less than complete participation of women, that currently constrain the development of the Indian market and companies in India, are also alluded to. A later section summarizes the other papers in this special issue. We conclude with recommendations for future economic policies in terms of which portions of the value chain India may emphasize, to best utilize its competitive strengths in international business.
\end{abstract}

Keywords India's competitiveness - India's human resource base and demographics - Indian multinationals · Institutional and regulatory constraints $\cdot$ Indian knowledge clusters $\cdot R \& D$ centers in India $\cdot$ Analyzing value chains for competitive advantage

F. J. Contractor $(\bowtie)$

Rutgers Business School, Newark, USA

e-mail: farok@andromeda.rutgers.edu

V. Kumar

The University of Sydney, Sydney, Australia

C. Dhanaraj

IMD, Lausanne, Switzerland 


\section{Introduction: India and its Global Connections}

In a globally interconnected economy, how is location still a source of competitive advantage? Can a country confer firm specific advantages to firms located within its boundaries, which in turn become the drivers for the internationalization of its firms? These are the questions that underlie this special issue on India.

Our premise is that location and country characteristics matter in international business, not only to draw investment from multinational enterprises (MNEs) but also to drive internationalization of its firms (Cantwell 2009; Dunning 1998). Global interconnectedness does not necessarily diminish the unique characteristics that give a country its competitive advantage, nor does it necessarily "flatten" the economic landscape. On the contrary, greater international interconnectedness, as in the case of India, and the gradual opening of the country to foreign direct investment (FDI) and trade, have accentuated many of the country's locational advantages. Despite the ups and downs over the period between 2000 and 2013, FDI inflows into India, its merchandise exports, and its services exports grew at an impressive rate of 16.1, 16.2 and $18.6 \%$ respectively, suggesting rapidly growing interconnectedness with the world economy (UNCTADstat 2014). India can thus be viewed as a natural experiment and example of an emerging nation's internationalization, to provide useful insights for the field of international business studies.

At the outset, we address two key questions that arise when one considers the internationalization of emerging market firms (EMFs), a subject which remains a hotly debated issue in many emerging markets. Because of fears of diversion of investment capital away from the domestic market and the government's desire to manage foreign exchange and interest rates, in many emerging markets, controls on capital outflows remain in place, despite liberalization of FDI inflow policies that have opened markets to foreign firms (Tseng and Cowen 2013). Second, for many scholars, a focus on emerging market firms then raises the question, "What is the special advantage, if any, that these EMFs have, that drive their internationalization?" especially if we assume that EMFs do not possess ownership advantages such as technology or global brands. We address this fundamental question that can be asked of all EMFs, with specific reference to India.

\section{Why Should Indian Firms Internationalize?}

International business research has highlighted several benefits of internationalization for emerging markets like India. We review four ways in which internationalization accentuates the locational advantages of these firms:

1. Highlighting natural endowments and comparative advantage,

2. Augmenting created advantages in terms of knowledge clusters, skills, supplier networks and institutions at the level of the industry or Indian state,

3. Cross-border human networks that create flows of ideas, technology and organizational routines, including the role of diasporas, and finally 
4. The growth of FDI and portfolio flows-inflows based on the growing attractiveness of the local Indian market to foreign investors, as well as the surge in Indian outward investment.

\section{India's Natural Comparative Advantage}

First, the natural or comparative advantage of a nation is more readily available and arbitragable, to countries with increasing interconnectedness. For instance, India's advantages in low cost farm labor and 9 months of sunshine motivate agribusiness FDI and international supply-chain contracts with Indian farms (Gulati et al. 2007). Indian companies can leverage India's advantage in skilled, English-speaking workers by arbitraging the difference between Indian and advanced nation salaries, in a range of professions from software engineers to doctors to materials scientists (Dahlman and Utz 2005). One can add the long historical traditions of entrepreneurship and administrative skills (at least in certain castes and Indian states) as a natural comparative advantage ${ }^{1}$ (Iyer et al. 2013).

\section{India's Created Advantages}

Secondly, interconnectedness helps create and augment country advantages. It germinates and fosters the formation of knowledge or skill clusters, industry agglomerations, and a network of ancillary or feeder firms. Porter and Kramer (2011) describe the diamond cutting cluster around the city of Surat, where the overwhelming majority of the world's diamonds are cut, polished and re-exported. Employment in the cutting workshops plus ancillary industries (machinery, chemicals, training schools, transport companies, and quality inspectors) is approaching 500,000 persons around the city of Surat itself (Hussain 2009). In the 1970s when socialist India even restricted travel of its citizens, some enterprising Gujaratis (Indians from the state of Gujarat) traveled to Antwerp and New York, and established initial connections with the diamond business. Starting with cutting of low grade diamonds, the skill cluster now handles stones of every quality level and value. The upgrading of skills and increasing value-added activities through internationalization of the Indian economy is a recurrent theme in a range of sectors.

Similarly, Saxenian (2005), tracing the evolution of the knowledge cluster in Bangalore and other Indian cities, indicates that “...Bangalore (being) home to India's leading university and government research centers, including the elite

\footnotetext{
1 The distinction between natural endowments or comparative advantage of a nation, and a created advantage, is a matter of historical timing. Indian entrepreneurial and administrative skills go back into pre-history, exhibited in international trade links between India, Rome, China and Southeast Asia that go back at least two millennia (Thapar 2002). By contrast, the formation of the IT cluster in Bangalore and other Indian cities dates mainly from the 1990s (Lorenzen and Mudambi 2013).
} 
Indian Institute of Science, the Center for the Development of Advanced Computing, and a range of telecommunications and defense-oriented research facilities," was perhaps necessary, but not a sufficient, condition for the development of the Indian IT industry. Rather, she avers, it was when US and European companies, faced with increased competitive cost-cutting pressures and the looming demand of Y2K fixes, started placing orders on Indian vendors in the year 1998, that the cluster really took off, (aided by the personal connections of Indian expatriates with the US' Silicon Valley). Today it would be correct to say that the more dynamic firms such as Infosys and Tata Consultancy Services (TCS) have gone considerably beyond the writing of software, as such, to what really amounts to IT-driven organizational change processes and management consulting. The evolution from IT to KPO (Knowledge Process Outsourcing) involved for India going from mere software writing (creating tools for other companies' information processing needs), to data processing, aggregation and data analysis, to harnessing knowledge into organizational wisdom in a consulting capacity. In financial services it meant Indian firms moving from software, to data management, to eventually designing algorithms for execution of trades and portfolio management (Currie et al. 2008).

In other sectors as well, Indian providers have moved from being "brick makers", to becoming architects and designers of the entire structure. For 36 years prior to 2005, India was looked upon unfavorably by the pharmaceutical industry because the country accepted pharmaceutical process patents, but not product patents. This enabled the emergence of a large generics sector based on reverse engineering (copying) of advance country drug compounds but then tweaking the synthesis (production) of the compound sufficiently so as to be able to file an alternative production process patent under the then Indian law (Mueller 2007; Greene 2007). The 36 years of protection to the Indian industry created enough of a base for expertise in the life sciences that, following 2005, under more stringent international competition (as a full observer of medical patents India received considerable new FDI in the pharmaceutical sector), India was able to move from "duplicative imitation to creative imitation" (Kale and Little 2007), and beyond that to do fundamental research. Between 2005 and 2014 the spate of acquisitions (Sun acquiring Ranbaxy; Abbott acquiring Piramal; Mylan acquiring Matrix Labs and Sanofi-Aventis acquiring Shanta Biotech, to give only a few examples) illustrate the confluence of three trends. India's human capital is rich in research-capable biologists, geneticists, and doctors whose salaries are less than one half or one-third the US level. ${ }^{2}$ And their supply is ample, thus far. Second, during this period, the Indian government opened its doors wide, allowing $100 \%$ shareholding by foreign investors. Third, if one multiplies the still minuscule per capita health care expenditures of the country by the 1.25 billion population size, we already have a respectably large market for pharmaceuticals - and indeed for firms in most other sectors as well. Factoring in a growth rate in health care expenditures that exceeds $12 \%$ annually, India's market potential is very attractive to the global industry.

\footnotetext{
${ }^{2}$ While India's primary education badly lags that of other emerging countries like China, its tertiary or higher education institutions produce a goodly supply of trained human capital, which at its best is comparable to any in the world.
} 


\section{India's Cross-Border Human Networks and Idea Flows}

The third aspect of India's interconnectedness with the rest of the world is through personal and organizational networks. Diasporas act as bridging agents between their nation of origin and foreign domicile, facilitating the flow of talent, ideas, technology, business opportunities, and investment capital (Contractor 2013; Ye 2014). The Indian diaspora is said to exceed 20 million worldwide, with three to four million in North America and over two million in Europe (The Economist 2011). More so in the US than in Europe, persons of Indian origin tend to be highincome professionals and successful entrepreneurs. The Indian diaspora has personnel and talent in all portions of the value chain in high technology industries ranging from IT to biotechnology and can therefore act as knowledge conduits for $\mathrm{R} \& \mathrm{D}$, production and marketing. So deep rooted are the network links between the US Silicon valley and the Indian IT hubs, that Saxenian (2005) cites reports that news about emergent application technologies, job vacancies and trends surfaces simultaneously in Palo Alto, Bangalore and Hyderabad. Expatriate venture capital flows from US funds (including Indian investors or partners) going to Indian startups, exceed well over a billion dollars a year in the IT sector. Since the turn of the century, the US government has issued skilled Indian citizens several hundred thousand H1-B visas that enable them to work in the US for several years. In July 2014 just one company, Flipkart (an Indian online shopping portal) raised over a billion dollars from private equity investors in the US and Singapore (Thoppil 2014).

A more important aspect than seed capital is the seeding of ideas. The crossborder flow of ideas is especially prominent in IT-enabled services, hospitality, medical devices and pharmaceuticals. Kapur and Ramamurti (2001) in their perspective on India's growing strength in services, note that overseas nationals have played a critical role in technology transfer, capital supply, information as well as in reputation building. They further note that while overseas Indians have helped boost exports of knowledge-based services, overseas Chinese have done so in labor-intensive manufactured products. Zaheer et al. (2009) studying eleven city clusters in India for services offshoring, found that ethnic networks exert greater influence on location decisions than cluster capabilities and externalities-and that this was more true for Indian, as opposed to foreign companies. Other academic studies on the role of diasporas in international business are relatively few and not necessarily focused on India. Leblang (2010) traces a statistically significant role for diasporas in augmenting FDI flows, while the Oettl and Agrawal (2008) study tracks patent citations to show how ideas flow across borders between ethnically related individuals and groups. These are augmented by case studies like Lorenzen and Mudambi's (2013) descriptions of the personnel links between the IT clusters in California and Bangalore and the nascent role of Indian investment in Hollywood as well as US investment in Bollywood (the Bombay, India-based film industry). 


\section{Cross-Border Capital Flows}

Considerable lamentation has been expressed over the fact that the growth rate of the Indian economy which was above $7 \%$ in the period 2000-2008, slowed since then to a mere $5 \%$ or so. But $5 \%$ growth would still be the envy of most other countries. Inflows of FDI into India that had slowed to below $\$ 25$ billion during the global recession now show signs of a resurgence with a new pro-business government in charge after 2014. More notably, outward FDI by Indian companies grew from only $\$ 514$ million in 2000 to around $\$ 16$ billion annually by 2010 (UNCTADstat 2014). ${ }^{3}$ While still small by advanced nation standards, the growth rate is high. Interestingly, as Karna et al. (2014) show in their exhaustive study of 7,238 Indian outward FDI investments between 2007 and 2013, $70 \%$ of such FDI was in wholly-owned subsidiaries in advanced as well as other emerging nationsas opposed to the lower risk, alliance and joint venture modes of entry chosen by multinationals in markets they are not familiar with. This betrays a level of confidence in Indian firms about their ability to operate independently in foreign environments. Another likely factor is that a number of the wholly-owned subsidiaries are the result of knowledge-seeking acquisitions (Gubbi et al. 2010). That is to say, the strategic motivation was not so much to develop foreign markets but gain accelerated access to advanced technologies resident in the target firms located in advanced nations (Luo and Tung 2007; Hennart 2012; Karna et al. 2014). As well, the pattern and fast outward internationalization of Indian firms suggests that many of them, if not exactly born-global (Knight and Cavusgil 2005), do not follow the traditional pattern of gradual incremental expansion into culturally or psychically similar markets (Johanson and Vahlne 2009). One sees a degree of boldness exhibited by few other emerging market based multinationals.

\section{What is India's Competitive Advantage?}

Thus far we have focused on India's connections with the rest of the world economy, from a bridging or arbitrage perspective. We now turn to India's innate, or bedrock characteristics that stem from its culture, or its history and its human capital. Not all of these characteristics are unalloyed advantages. For example, viewpoints vary as to the benefit/cost ratio of family or holding company structures, especially if the group operates in unrelated product sectors.

\section{Group and Family Businesses}

From the corner grocery store to giant enterprises, ultimate control in Indian companies rests in very few hands. This is not unlike other countries such as South

\footnotetext{
3 This represents a compound annual growth rate of 41 percent, but from an initially very low base because of earlier restrictions imposed by the Indian government on outbound FDI. Outward FDI from India declined after 2011 to average around \$ 10 billion with signs of a renewed surge in 2014. The overall picture is still one of rapid outward internationalization by Indian companies.
} 
Korea which have already 'emerged' and become affluent societies, and yet retain their closely-held business structures. Despite thriving financial markets, with millions of shareholders, strategic decision making is highly centralized at the apex level. With a liberalizing economy, opening up to greater competition, the western model of professional management with devolved decision making should displace the closely-held or family enterprise. Worse, according to finance theory, unrelated product diversification (or multi-product business groups as seen in emerging nations from Turkey to India and even in rich countries like Korea) should reflect disadvantages of such a structure that exceed its advantages. Yet Khanna and Palepu (2010) find no signs of its disappearance.

Contractor (2013) asks if the advantages of private equity and family control outweigh the disadvantages and result in superior performance, both domestically and internationally, as exemplified by very diversified holdings in groups such as the Koç family group of companies based in Turkey or the Tata Group ${ }^{4}$ from India that are successful multinationals. Family control, in an emerging country context, can have advantages over professionally run organizations, by the ability to make quicker decisions, willingness to be patient or take a long-term strategic view (Serrasqueiro et al. 2012). Families in emerging nations including India are very large or extended and their social or informal networks can reach across states and national borders, yielding a rich crop of ideas, insights and capital (Zaheer et al. 2009; Ahlstrom et al. 2007; Luo 2003). Of course, the entrepreneurship literature (e.g., Carlock and Ward 2010) also suggests disadvantages of family-held businesses. However, their advantages, in the Indian milieu, are hypothesized to typically outweigh their drawbacks. As Khanna and Palepu (2010) aver, the very existence of "institutional voids" (imperfect markets in supply chains or talent, imperfect laws, etc.) gives family and closely-held companies an advantage because their internal processes, extended ties and reputation substitute for functioning markets and institutions.

Similarly, the fact that unrelated product diversification in business groups persists and even thrives in the emerging nation context, appears to run counter to received wisdom in finance theory. What is it about India that enables unrelated product group companies like Tatas or the Reliance Group to exist? The answer may lie in their internal processes within the apex holding structure and in social, financial and knowledge ties across individual group companies that substitute for external markets (which either do not exist, or are very imperfectly developed in an emerging nation). For example, Indian firms rely more on internally developed managerial and technical talent than in advanced nations where job markets are well developed. The tradition of the generalist manager is still preferred over the

\footnotetext{
4 The Tata companies are no longer family controlled, and are individually listed on public stock exchanges. However, a holding company (Tata Sons) controls the biggest single bloc of shares in each Tata firm, the rest being widely dispersed over the public and financial institutions. The holding company wields power by retaining enough voting shares, by the fact that other blocks of shares are held by investors who are content to take a passive role, by the cultural acceptance, or tradition, of ultimate authority being centralized, and by charging a royalty to each group company for the use of the Tata brand name. The royalties earned are, in turn, used to purchase even more shares in each group company, or start new ventures.
} 
functional specialist, and seasoned managers are groomed and rotated between the group companies, giving senior management a broader strategy experience, as well as binding group companies through internal social networks. (Many of the larger Indian companies such as Infosys and Tata have also developed extended international social networks that mobilize global talent, ideas and capital across borders).

In an environment where there are institutional "voids"-independent quality ratings are infrequent, consumer protection is scarce, are where legal recourse is nonexistent or may take decades to effect-group reputation confers a significant advantage. The group corporate name is an asset even in developed societies (Fombrun 2006) but is especially valuable in countries like India. For example, the Tata or Reliance brands give assurance to customers and command a market premium, be it in automobiles, mobile telephony, tea, watches, power generation, or petrochemicals — an otherwise bewildering mixed-bag of product types.

Group membership also facilitates the raising of investment capital in several ways. As noted, group reputations facilitate IPOs in the Indian stock markets, and enable borrowing at more favorable rates (than if they were stand-alone companies). Moreover, internally raised capital can substitute for market capital. The apex holding company, Tata Sons, charges each group firm a royalty for the use of the Tata brand name, and the royalty streams aggregated over dozens of group companies becomes a tidy source of new venture capital. This is analogous to the principal source of capital in the US motel sector (where around $55 \%$ of US motels are owned by persons of Indian origin) being family and caste ties among the caste of Gujarati Patels, each family contributing a sum to the investment pool of a motel (Dhingra 2012). ${ }^{5}$

The larger Indian business groups have also developed internalized expertise (that can be then shared across group firms at very low incremental learning costs) in global supply chain management, government relations and human resource management (HRM). HRM expertise now extends internationally in a few firms. Infosys recruits graduates at business and engineering schools in Europe and the US, and Mahindra and Mahindra (an Indian automobile firm that has successfully sold auto components and vehicles in Spain) has recruited senior European engineers to upgrade their technology. These are harbingers of an emerging trend (Philip and Vijayraghavan 2011).

Despite the above mentioned advantages that group companies have over their unaffiliated counterparts, recent literature has questioned its sustainability in emerging nations in the future. An underlying premise of many of the advantages of group companies emanate from the weak and inefficient institutional context in the emerging markets (Khanna and Rivkin 2001). However, institutions and factor markets in the emerging countries have been evolving (Hoskisson et al. 2013) with the steady introduction of an array of pro-market reforms (Chari and David 2012, Cuervo-Cazurra and Dau 2009). This has facilitated in developing a more levelplaying field for unaffiliated companies, which a study by Zattoni et al. (2009)

\footnotetext{
5 Dwivedi (2010) also suggests that another ingredient of business success in Gujarati-owned motels in the US is the use of family members and immigrants as employees.
} 
shows have outperformed group companies in the more recent years in the context of relatively better developed institutions. The issue of group advantages becomes more contentious when observed in the international context with evidence on both sides. While Gaur and Kumar (2009) and Chittoor et al. (2009) suggest an international discount associated with group affiliation, Elango and Pattnaik (2007) and Lamin (2013) argue the opposite for a positive association with internationalization. Such potential contradictions in findings may possibly be resolved by looking at specific facets of internationalization and how group affiliation plays a role in influencing those international initiatives as well as by focusing more on organizational transformation taking place within these business groups.

\section{India's Human Capital}

The wealth of a nation lies ultimately in the quality of the thinking of its population, which in turn is based on education. Market size is a function of levels of education and affluence (which are correlated) as well as population size. In a decade or less India is slated to surpass China to become the nation with the largest population. This, accompanied by quickly rising purchasing power and education levels, could position India to become one of the most exciting markets in the decades following 2020. On the supply or production side, Total Factor Productivity (TFP) in manufacturing in India was shown to correlate positively with literacy rates, in a study by Kathuria et al. (2013) covering the period 1994-2005. Whereas TFP has been associated in most studies with $R \& D$, openness of the economy and institutional development, this study shows the important role of literacy in efficiency in an emerging nation.

Compared to other emerging countries like China, Indian literacy rates, as well as the share of manufacturing output in GDP or trade, are currently lower. But therein also lies India's future potential. With investments in basic and technical education accelerating, India already offers millions of trained and capable persons in the entire range from unskilled workers to scientists. In the development of human resources, India is in a 'catch-up' mode. Its indicators lag compared to say China, as indicated in Table 1. (The USA is included for comparison purposes because it is the third largest population country ${ }^{6}$ ). India's number of individuals participating in the labor force (i.e., the organized sectors of the economy) is just $60 \%$ that of China's (481 million compared to 793 million). The reasons have to do with India's currently much smaller manufacturing base compared to China's; larger percentages in informal and agricultural sectors; and societal values that hitherto have discouraged rural females from working outside the home (India's adult female participation rate is just $27 \%$ compared to China's $64 \%$ in Table 1). India's adult literacy rate of $73 \%$ considerably lags those of other emerging nations (and in particular, female literacy is estimated to be approximately only 45-50 \%).

However, while India's indicators have lagged other emerging nations, three trends already under way, presage a bright promise for the coming decades. First,

\footnotetext{
${ }^{6}$ The US is also the world's second biggest manufacturer by value of output.
} 
Table 1 Human capital indicators (2010-2013): China, India and USA comparisons

\begin{tabular}{llllll}
\hline $\begin{array}{l}\text { World's three } \\
\text { largest } \\
\text { population } \\
\text { nations }\end{array}$ & $\begin{array}{l}\text { Number of } \\
\text { individuals in } \\
\text { labor force } \\
\text { (millions) }\end{array}$ & $\begin{array}{l}\text { Percentage of } \\
\text { adult females } \\
\text { in labor force }\end{array}$ & $\begin{array}{l}\text { Adult }{ }^{\text {a }} \text { literacy } \\
\text { rates } \\
\text { (percentage of } \\
\text { all adults) }\end{array}$ & $\begin{array}{l}\text { Young } \\
\text { adult }^{\mathrm{b}} \\
\text { female } \\
\text { literacy } \\
\text { rates }\end{array}$ & $\begin{array}{l}\text { Female to male } \\
\text { \% enrolled in } \\
\text { secondary } \\
\text { education }\end{array}$ \\
\hline China & 793 & 64 & 95 & 92 & 102 \\
India & 481 & 27 & 73 & 62 & 94 \\
USA & 159 & 56 & 98 & 99 & 100 \\
\hline
\end{tabular}

Sources: World Bank (2014); CIA World Factbook (2014)

a Ages 15 and older

b Females between 15 and 24

Indian government policies have in the past decade belatedly begun to emphasize primary and secondary education, especially for females. India's lagging indicators in the last three columns of Table 1 are bound to catch up with positive effects on both purchasing power (market size) and quality of workers. Secondly, urbanization and social changes are rapidly altering attitudes, and injecting more workers and better educated workers into the formal labor force (Nielsen and Waldrop 2014).

Thirdly, overall demographic trends, can give India an excellent potential "Demographic dividend" in the 2020-2040 time period. Using United Nations estimates for India, Bloom (2011) projects that India could soon have the largest labor force in the world and even more significantly, have a very favorable 'Working Age to Non-Working Age' ratio as seen in Fig. 1. By contrast, in China and East Asia, this favorable trend had already peaked by 2010 as seen in Fig. 1. With a static labor supply in China, wages have risen rapidly since 2010, to the point where some manufacturing in China is no longer deemed competitive. Indeed, some production is leaving China and relocating in certain ASEAN countries and India (Zhang 2013).

On the cautionary side, the "demographic dividend" may not transpire if fertility rates in India drop precipitously (see the low estimate for India in Fig. 1) or if bureaucratic and infrastructural bottlenecks to economic growth in India are not alleviated. If so, a high demographic projection may only mean that millions of educated Indians will have no jobs, which is a recipe for future political instability.

\section{India's Innovative Capacity}

A brick-makers to architects transition is underway not just in the production portion of the value chain but also in R\&D (Altenburg et al. 2008). Five Indian firms appeared on the Forbes 2014 list of the world's most innovative companies despite a proprietary selection algorithm that handicaps firms based in emerging nations ${ }^{7}$

\footnotetext{
${ }^{7}$ The selection algorithm is biased against firms located in rapid-growth economies on the grounds that part of such emerging nation company dynamism can be explained simply by the growth rates of their markets.
} 


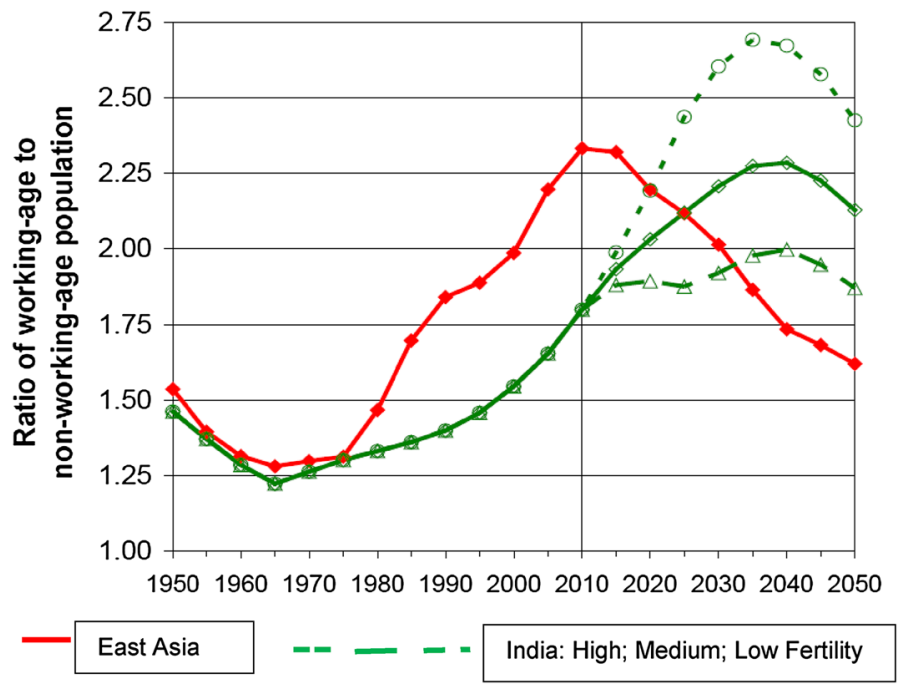

Fig. 1 Working age to non-working age ratios, India and East Asia. Source: Bloom (2011) from United Nations data

(Dyer and Furr 2014). One of the five, Hindustan Level (a Unilever subsidiary) stands out for 'bottom of the pyramid' innovations in product design and distribution methods that have then been 'reverse-transferred' to other Unilever affiliates internationally. The other four firms, Tata Consultancy Services (TCS), Sun Pharmaceuticals, Larsen \& Toubro and Bajaj Auto all illustrate the rapid evolution of their R\&D capabilities. From low level software coding and call centers 20 years ago, TCS is now better depicted as an IT-driven strategy and organizational change consultancy to some of the biggest client firms in the US and Europe. The IT sector, in general is a shining spot for Indian innovation. IBM stopped disclosing the number of employees in its various subsidiaries worldwide because of the politically embarrassing possibility that IBM today may have more employees in India than in the US. Certainly, several of the IBM India employees are devoted to local market sales. However, a large number are engaged in R\&D, as is the case with $\mathrm{R} \& \mathrm{D}$ centers established in India by an estimated 870 multinationals by 2012, ranging from Texas Instruments to Intel to GM and GE (Knowledge at Wharton 2012). Such R\&D center in India possibly exceed a thousand today. According to a study by Zinnov Consultants, India's internationally traded R\&D services, including those by contract research companies, amounted to a value of $\$ 18.3$ Billion which they say is a third of internationally traded R\&D services worldwide (Hindu Business Line 2014). This figure underestimates the actual value by far because $R \& D$ performed by the Indian subsidiaries of foreign MNEs (with the knowledge then transferred back to the MNE parent and other affiliates) is not included.

A significant part of this R\&D capability in India is explained by the numbers of Science and Engineering graduates. A far back as 2008, Gereffi et al. (2008) 
reported that compared to the US' 120,000 Bachelor's degrees in engineering and technology (half of whom may be foreign students who will not remain in the US), India graduated 230,000 and China nearly 600,000. Even if one discounts say the bottom $80 \%$ of those figures as being graduates of questionable quality, that still leaves 46,000 annual technology graduates in India of acceptable to world-class standards. (Gereffi et al.'s figures specifically excluded the 2,300 graduates from the Indian Institutes of Technology, generally recognized to be amongst the brightest in the world). The result is a large pool of scientific and technical talent willing to accept salaries as low as \$15,000 per annum and generally not exceeding $\$ 80,000$ even for senior scientific personnel.

R\&D in India is developing in three directions, (1) Global new product development, (2) Cost-reducing and efficiency seeking innovations, and (3) Process and product development synergistically aided by IT applications. The first is cutting-edge research directed at new product innovation in a wide range of fields from drug research (Haakonsson et al. 2013) to automobile design (Motohashi 2014), to chip design (Fuller 2014) with revenue-enhancing product developments applicable not just to India, but to products that will be sold around the world.

The second direction for Indian $\mathrm{R} \& \mathrm{D}$ is in local adaptation, aimed at cost reduction and efficiency gains, sometimes described as "frugal innovation". In the latter category are by now famous examples of GE's Indian unit designing strippeddown EKG and ultrasound medical devices (Kumar and Puranam 2012) and hospitals like Narayana Hrudalaya which apply industrial engineering techniques to hospital management whereby they are more than $250 \%$ as efficient as American or European hospitals - not just in financial indicators such as cost per surgery, but also in non-financial productivity measures such as surgeries per doctor or annual patient throughput per square meter of space (Knowledge at Wharton 2010). But these innovations are not useful just in the Indian market, but stand to infuse and change practices worldwide as local knowledge is diffused to other nations. ${ }^{8}$

The third direction in Indian innovation is applying India's strength in IT applications to industrial and managerial processes in general. This is discussed in the section below.

\section{India's Competitive Advantage from IT-Enabled Services}

Expertise in Information Technology (IT) confers advantages on Indian companies both domestically and internationally. Bhattacharya and Michael (2008) relate how, in a decentralized rural landscape, IT-enabled technologies used by a milk cooperative-

\footnotetext{
8 Admittedly, some innovations may not have much applicability beyond other developing countries. Examples include a non-mechanical refrigerator which consists of a special Indian mud covering a sealed box that serves as a refrigerator. This special Indian mud coating has porosity characteristics that allow for significant evaporative cooling-provided, of course, that the user regularly replenishes the water in the pan-an idea unlikely to appeal to affluent consumers. For millennia, Indians have been using charcoal as a dentifrice, and such preparations are sold commercially. It was thought impossible that consumers in other nations would be willing to put charcoal in their mouths-until in 2014 Colgate introduced Colgate Total Charcoal toothpaste and activated charcoal toothbrushes.
} 
Gujarat Cooperative Milk Marketing Federation, better known by its brand name "Amul"-sources and distributes 6.5 million liters of fresh milk each day, and overcomes problems endemic to emerging countries, (a) the fear of farmers that they will be cheated out of their rightful dues and not be paid promptly, (b) concern on the part of the cooperative that they procure unadulterated milk of the right quality, with the correct fat and nutritional content, measured accurately, and (c) the typical concern of emerging nation consumers about receiving clean milk, as advertised by the company. Previously, each collection agent at the farm would weigh the milk manually. The testing of samples would take place in a centralized facility from which test results would be issued after several days and the dairy farmer paid. Farmers used to be naturally suspicious, and the central testing facilities sometimes overwhelmed. Today the agent on the farm uses automated equipment for testing samples on the spot and transmits the transaction data by mobile phone or satellite in real time. The farmer is paid immediately, on the spot, after being shown the test results. More than a million transactions are handled each day, with almost no complaints. An Enterprise Resource Planning (ERP) system handles forecasts for supply, demand, pricing, and road transport logistics for time horizons ranging from $48 \mathrm{~h}$ to 3 months. Consumers all over India have come to trust the Amul brand as signifying quality and reliability. The cooperative is a model of efficiency that can rival any in the world, and yet operates on a large scale seen in very few nations. Once in place, with demand for milk still rising in the emerging middle class which is already 600 million strong, the ERP system can be scaled up at low incremental cost. This example shows how IT-enabled services enable Indian organizations to exhibit cutting-edge competitiveness. Bhattacharya and Michael (2008) also indicate that a few Indian banks such as HDFC and ICICI, if freed from the still-onerous constraints on Indian financial services, could easily hold their own against foreign rivals like HSBC or Standard Chartered.

Numerous similar examples from Indian business can be quoted. However, the Unique Identification initiative of the Indian government may become a game changer for a range of state as well as relevant private enterprises. Through this national identity program, every Indian citizen will have a unique digital identity which can be used to reduce transaction costs that plagues almost all spheres of life in India. Most importantly, it can enable public and private companies to tackle pressing needs related to providing health care and basic amenities to remote and rural locations.

One of the major constraints to competitive advantage derived from IT-enabled services in India is the lack of internet connectivity. While over 600 million people use mobile phones in India, only about a fourth regularly connect to the internet and the country's internet penetration rate stands at only half of that for all developing countries (Schmidt 2013). This is bound to change, unleashing with it enormous potential for companies to benefit from a radically different and digitally connected India.

\section{Papers in this Special Issue}

This focused issue begins with a provocative essay by Khanna on "contextual intelligence". The essay goes much beyond simply reinforcing the importance of "context" in international business research, by questioning the efficacy of the 
"mental models" that are typically embedded in certain specific frameworks, and in addressing novel and pertinent research issues of the proximate future. This essay underscores one of the key motivations for using India as a theme for this focused issue, In order for international business research to move to the next level, we need to explore and investigate research questions from the perspective of the context in which the phenomenon is primarily occurring. Generalizing findings derived in one context to others is problematic and unnecessary. The plethora of research on emerging market firms over the last decade is clearly indicative of the lack of general applicability of frameworks and theories related to internationalization, which are developed with a "Western" bias.

The next paper, by Narula, touches upon a unique characteristic of many emerging markets, particularly that of India. The simultaneous existence and growth of two types of economies, one of which is knowledge-intensive and is classified as 'modern' and other which is resource-intensive and is classified as 'traditional', is an attribute of any economy. However, the pertinence of such a "dual economy" is especially apparent in emerging markets such as India. Narula utilizes this distinguishing characteristic to argue that this duality, in location-specific assets as well as in ownership-specific assets, are factors that will shape the internationalization patterns of Indian MNEs. While arguing for the key role that the locationspecific assets will play in Indian MNE's international expansion, Narula, paints a less-than-optimistic picture about Indian MNEs sustaining international competitiveness based on his logic of constraints that these firms will face in accessing knowledge in the long run. We believe that knowledge infrastructure in India, while still weak, can improve dramatically with concerted long term investment. As and when this takes place, even smaller Indian firms with fewer resources will become beneficiaries and can transform their international competitiveness.

The third paper, by Prashantham and Birkinshaw, considers the role of homecountry relationships in the internationalization of Indian firms from the IT sector. Social networks, clearly, are an important feature of doing business in Asian economies including that of India. However, what is less clear is what specific types of networks or relationships are more likely to enable firms to progress in their international expansion initiatives. Prashantham and Birkinshaw combine the reference group theory with social capital theory to posit that it is ties with certain special types of groups (aspirational local industry groups), instead of ties in general with firms in the local home market, that lend advantages in the internationalization of young Indian firms. The findings here are interesting in the sense that they reveal the effect of somewhat ambiguous notions such as "aspiration" on internationalization of firms. This is unique to emerging market firms and broadens the scope of factors that come into play when considering the internationalization of emerging market firms.

The fourth paper, by Gaur and Delios, directly incorporates the contextual aspect of India and other emerging markets into their examination of the relationship between ownership structure and international diversification of firms. The impact of domestic and foreign investors' concentration, along with business group affiliation, is examined on internationalization propensity. More interestingly, they show that the performance consequence of internationalization of Indian firms is 
contingent on ownership structure and group affiliation. Their results pertaining to the internationalization-performance nexus turns out to be negative and not U-shaped as hypothesized in their study. This reinforces the notion of being extremely cautious in generalizing our research findings. ${ }^{9}$

The fifth paper, by Chittoor, Aulakh and Ray, examines the role of ownership characteristics of Indian firms on their propensity to internationalize through acquisitions. Acquisition is a preferred mode of international expansion for several emerging market firms, including those from India, as this allows for rapid internationalization as well as access to much needed resources and markets. However, acquisition is also a risky strategy—one which requires a high level of commitment. Chittoor et al.'s paper argues that ownership characteristics such as CEO international experience, concentration of shareholding by foreign institutional players and promoters, and business group affiliation affects the risk-taking propensity of the firm, ultimately impacting the likelihood to engage in international acquisitions. The behavioral risk-taking perspective of this paper complements the institutional theory perspective adopted in the Gaur and Delios paper to analyze internationalization of Indian firms. Group affiliation is posited to positively moderate the effect of internationalization on performance in Gaur and Delios. However, Chittoor et al. argue that this constrains the risk-taking propensity of firms for engaging in international acquisitions. This aspect highlights the importance of carefully analyzing the role of group affiliation separately for different facets of internationalization.

The final paper, by Nair, Demirbag and Mellahi, examines the reverse knowledge transfer that takes place in Indian MNEs. This paper pushes the boundaries of research on emerging market firms by looking specifically at the subsidiary level factors, which is rare in studies on emerging market firm internationalization. While the findings are quite intuitive, this paper provides a further explanation for the strength of the Indian technology sector. They show that a higher level of collaboration between the foreign subsidiary and parent is useful in facilitating knowledge transfer in high technology and knowledge-intensive industries, compared to others. In addition, they demonstrate that subsidiaries in more competitive locations, such as developed nation markets, are more useful in transferring knowledge back to the parent in India.

\section{Conclusions: India's Future Role in the Global Economy}

Despite an almost comparable size population and somewhat lower wage rates, India's manufacturing output is less than one-quarter that of China's. Each year in India, some ten to twelve million young men reach the age of eighteen, presumably looking for productive employment. Not all find it. As Chinese wage rates have

\footnotetext{
9 An alternative ex post hypothesis could be that the firms in their sample being relatively early internationalizers, the benefits of early internationalization are exceeded by the incremental costs of early internationalization as proposed by the general theory (Stage I international expansion) in Contractor et al. (2007), resulting in a negative slope for the performance-internationalization relationship in the case of early international expansion.
} 


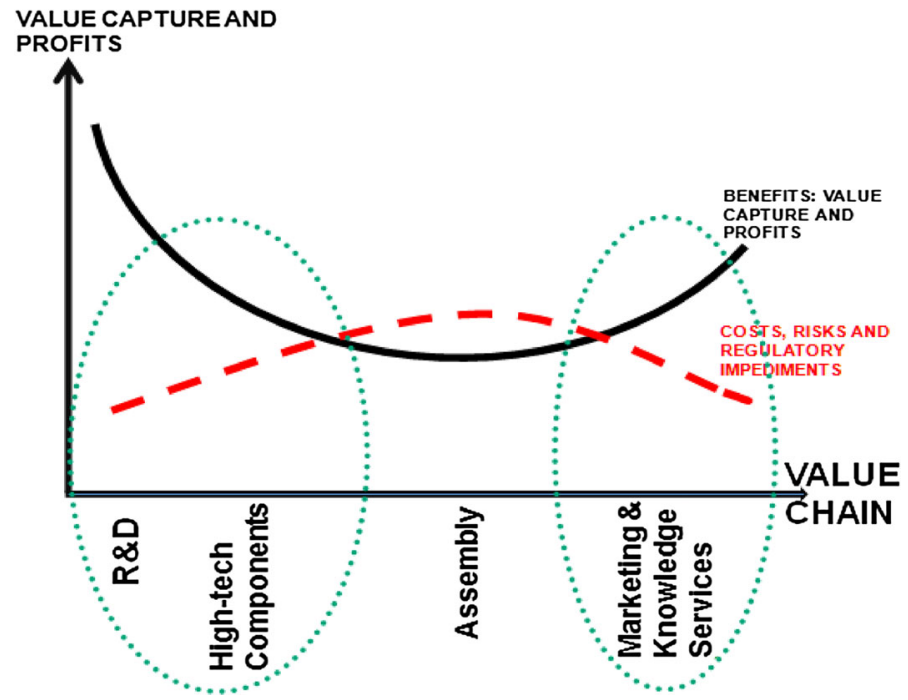

Fig. 2 India's international competitiveness lies in which portion of the value chain?

risen in its eastern seaboard at between 10 and $15 \%$ annually since 2010, and the RMB (Renminbi Yuan) has appreciated by over $32 \%$ since 2005, many feel that low-end manufacturing and assembly operations in China are no longer competitive. Already in 2014, some Chinese operations have been relocated to lower wage nations. But have they migrated to India? Should India encourage FDI in mass production and assembly operations?

Figure 2 shows the familiar "smiling curve" hypothesis ${ }^{10}$ about the profitability (shown in the solid line and vertical axis) over various portions of the value chain (horizontal axis). The "smiling curve" or U-shaped profitability curve suggests that the middle portion of the value chain-manufacturing and assembly-is less profitable because it lack any distinctiveness for a nation, except for the advantage of cheap labor. The more profitable portions of the value chain are upstream in $\mathrm{R} \& \mathrm{D}$, as well as downstream in creative marketing and brand development.

This is relevant to emerging nations like China who currently feel trapped in the middle. For an iPhone that retails for over $\$ 600$ the direct costs of assembly by the outsource provider Foxconn (China) are estimated to be as low as \$10-12 per unit (Dediu 2012). Assuming Apple Inc.'s strong bargaining power over a contract assembler like Foxconn, the latter probably does not earn compensation much more than $\$ 12$, although vanishingly thin margins earned by Foxconn are offset by the sheer volume of millions of units assembled. Nevertheless, since the technology, design and brand value continue to reside in the hands of Apple, there would appear to be no future incremental profit potential for an assembler such as Foxconn. At the same time, with the Chinese labor force having peaked in 2010 (as illustrated in

\footnotetext{
10 The expression of the "smiling curve" is attributed by Bartlett and Ghoshal (2000) to Stanley Shih, former CEO of Acer.
} 
Fig. 1 above), companies like Foxconn have been squeezed by wage inflation exceeding $10 \%$ per annum.

Should India take over manufacturing from China? The answer is not clear. Certainly, for the domestic market, local manufacturing is often a logical or only choice compared to imports, in order to overcome the additional costs of transport, tariffs, and non-tariff barriers. But for international markets, the higher costs and risks imposed by outdated Indian labor laws (Krishnan 2014), strong unions, poor infrastructure, corruption and a hitherto strangling bureaucracy that still impedes business, mean that in the middle of the value chain the drawbacks (depicted in Fig. 2 in the red dashed line) often exceed benefits. Or at least, it puts India in an uncompetitive position in international markets vis-à-vis Vietnam, other ASEAN nations and even China, despite its higher wages and changing demographics.

Where India can do better is in the upstream and downstream potions of the value chain where regulatory and institutional obstacles are lower (i.e., impediments, regulatory and other risks are lower than in manufacturing and assembly) and where Indian creativity and acumen can have freer play. In value chain segments such as $\mathrm{R} \& \mathrm{D}$, marketing and brand development, which contain more intangibles or knowledge value, these are ipso facto less subject to government regulation and less dependent on good infrastructure, compared with tangible manufactures. In research or marketing, knowledge workers such as scientists and marketers are unlikely to be unionized. Skilled labor is more disciplined and a better bargain (in productivity measures like value-added per Rupee wages) than assembly workers. It is no surprise that the IT sector in which India is internationally competitive developed in the 1980s and 1990s 'under the radar' of formerly onerous Indian regulations that stifled manufacturing. According to Contractor and Kundu (2004) Indian bureaucrats did not quite know how to treat this nascent sector since it dealt with intangible products, was initially small, did not depend on roads, ports or permissions, and they left it alone also because it was a foreign exchange earner.

The hypothesis depicted in Fig. 2 is that compared to manufacturing and assembly, India's competitive advantage lies in the higher-value and more creative portions of the value chain, on either side of the middle. Examples already exist such as pharmaceutical research in companies such as Sun Pharmaceuticals, Suzlon in the alternative energy field, high level software development, hardware architecture and chip design in the Indian research units of Intel, SAP or IBM, and systems engineering. In marketing or downstream services, examples of Indian creativity are illustrated by Nielsen India (market research and big data management), Tesco Hindustan (retail management) and a number of data centers that support post-launch sales force management and risk monitoring for pharmaceutical companies worldwide.

This not to completely rule out the international competitiveness of Indian manufacturing. Indeed there are several existing and potential areas of success, such as the engineering and auto components clusters near Pune and Chennai, the refining of crude oil in Gujarat State for re-export as diesel or jet fuel, or the nascent export of finished automobiles by companies such as Suzuki, Ford, Nissan and Mahindra \& Mahindra. But manufacturing faces greater obstacles than services and 
knowledge processing, (obstacles which the new Indian government in 2014 says it wishes to remove).

In conclusion, this paper proposes for India the possibility of a bright future. A better educated and growing middle class will comprise not only one of the biggest markets in the world, but is growing more vocal in its demands for good governance. Economic history shows that societies where the median age is declining exhibit vigor and dynamism. Demographics which will increase still further an already favorable ratio, of working individuals to non-working dependents, should make India a more vibrant and large market, if the energies of the coming young cohorts are allowed freedom of expression in decent or creative jobs. The ghosts of the past, such as the hurt from colonialism, xenophobia and socialist sclerosis are rapidly fading. A raucous but functional democracy, a large fraction of society that is free market oriented, and at the apex, talent that can hold its own against the best on the planet, all these indicators presage a prosperous future and greater international business connectedness.

\section{References}

Ahlstrom, D., Bruton, G., \& Yeh, K. (2007). Venture capital in China: past, present, and future. Asia Pacific Journal of Management, 24(3), 247-268.

Altenburg, T., Schmitz, H., \& Stamm, A. (2008). Breakthrough? China's and India's transition from production to innovation. World Development, 36(2), 325-344.

Bartlett, C. A., \& Ghoshal, S. (2000). Going global: lessons from late movers. Harvard Business Review, $78(2), 132-142$.

Bhattacharya, A. K., \& Michael, D. C. (2008). How local companies keep multinationals at bay. Harvard Business Review, 86(3), 84-95.

Bloom, D. E. (2011). Population dynamics in India and implications for economic growth. WDA-Forum, University of St. Gallen. (mimeo).

Cantwell, J. (2009). Location and the multinational enterprise. Journal of International Business Studies, $40(1), 35-41$.

Carlock, R. S., \& Ward, J. L. (2010). When family businesses are best: the parallel planning process for family harmony and business success. Basingstoke: Palgrave Macmillan.

Central Intelligence Agency (2014). The World Factbook. Washington: Central Intelligence Agency.

Chari, M. R., \& David, P. (2012). Sustaining superior performance in an emerging economy: an empirical test in the Indian context. Strategic Management Journal, 33(2), 217-229.

Chittoor, R., Sarkar, M., Ray, S., \& Aulakh, P. S. (2009). Third-world copycats to emerging multinationals: institutional changes and organizational transformation in the Indian pharmaceutical industry. Organization Science, 20(1), 187-206.

Contractor, F. J. (2013). "Punching above their weight": the sources of competitive advantage for emerging market multinationals. International Journal of Emerging Markets, 8(4), 304-328.

Contractor, F. J., Kumar, V., \& Kundu, S. K. (2007). Nature of the relationship between international expansion and performance: the case of emerging market firms. Journal of World Business, 42(4), 401-417.

Contractor, F. J., \& Kundu, S. (2004). The role of export-driven entrepreneurship in economic development: a comparison of software exports from India, China, and Taiwan. Technological Forecasting and Social Change, 71(8), 799-822.

Cuervo-Cazurra, A., \& Dau, A. (2009). Promaket reforms and firm profitability in developing countries. Academy of Management Journal, 52(6), 1348-1368.

Currie, W. L., Michell, V., \& Abanishe, O. (2008). Knowledge process outsourcing in financial services: the vendor perspective. European Management Journal, 26(2), 94-104. 
Dahlman, C. J., \& Utz, A. (2005). India and the knowledge economy: leveraging strengths and opportunities. Washington: World Bank Publications.

Dediu, H. (2012). How much does it cost to manufacture an iPhone? http://www.asymco.com/2012/02/ 22/the-iphone-manufacturing-cost-structure/. Accessed 22 Feb 2012.

Dhingra, P. (2012). Life behind the lobby: Indian American motel owners and the American dream. Stanford: Stanford University Press.

Dunning, J. H. (1998). Location and the multinational enterprise: a neglected factor? Journal of International Business Studies, 29(1): 45-66.

Dwivedi, M. (2010). Gujarati Diaspora on a global platform: perceptions, contributions and experiences. Diaspora Studies, 3(2), 161-185.

Dyer, J \& Furr, N. (2014). The world's most innovative companies. Forbes, http://www.forbes.com/ innovative-companies/. Accessed 20 Aug 2014.

Elango, B., \& Pattnaik, C. (2007). Building capabilities for international operations through networks: a study of Indian firms. Journal of International Business Studies, 38(4), 541-555.

Fombrun, C. (2006). Corporate reputations as economic assets. In M. A. Hitt et al. (Eds.), The Blackwell handbook of strategic management (pp. 289-312). Oxford: Blackwell.

Fuller, D. B. (2014). Chip design in China and India: multinationals, industry structure and development outcomes in the integrated circuit industry. Technological Forecasting and Social Change, 81(1), $1-10$.

Gaur, A. S., \& Kumar, V. (2009). International diversification, business group affiliation and firm performance: empirical evidence from India. British Journal of Management, 20(2), 172-186.

Gereffi, G., Wadhwa, V., Rissing, B., \& Ong, R. (2008). Getting the numbers right: international engineering education in the United States, China, and India. Journal of Engineering Education, 97(1), 13-25.

Greene, W. (2007). The emergence of India's pharmaceutical industry and implications for the U.S. generic drug market. Working Paper No. 2007-05-A, Office of Economics, U.S. International Trade Commission.

Gubbi, S. R., Aulakh, P. S., Ray, S., Sarkar, M. B., \& Chittoor, R. (2010). Do international acquisitions by emerging-economy firms create shareholder value? the case of Indian firms. Journal of International Business Studies, 41(3), 397-418.

Gulati, A., Minot, N., Delgado, C., \& Bora, S. (2007). Growth in high-value agriculture in Asia and the emergence of vertical links with farmers. Paper presented at the workshop "Linking small-scale producers to markets: old and new challenges." The World Bank, 15 December 2005.

Haakonsson, S. J., Jensen, P. D. Ø., \& Mudambi, S. M. (2013). A co-evolutionary perspective on the drivers of international sourcing of pharmaceutical R\&D to India. Journal of Economic Geography, 13(4), 677-700.

Hennart, J. F. (2012). Emerging market multinationals and the theory of the multinational enterprise. Global Strategy Journal, 2(3), 168-187.

Hindu Business Line (2014). R\&D centres in India account for $33 \%$ of global services market, says Zinnov study. The Hindu Business Line. http://www.thehindubusinessline.com/features/smartbuy/ tech-news/rd-centres-in-india-account-for-33-of-global-services-market-says-zinnov-study/ article6446526.ece. Accessed 25 Sep 2014.

Hoskisson, R. E., Wright, M., Filatotchev, I., \& Peng, M. (2013). Emerging multinationals from midrange economies: the influence of institutions and factor markets. Journal of Management Studies, 50(7), 1295-1321.

Hussain, S.S. (2009). A diamond's journey: on the cutting edge. NBC News. http://www.nbcnews.com/id/ 15842527/ns/world_news/t/diamonds-journey-cutting-edge/ Accessed 26 June 2009.

Iyer, L., Khanna, T., \& Varshney, A. (2013). Caste and entrepreneurship in India. Economic \& Political Weekly, 48(6), 52-60.

Johanson, J., \& Vahlne, J.-E. (2009). The Uppsala internationalization process model revisited: from liability of foreignness to liability of outsidership. Journal of International Business Studies, 40(9), 1411-1431.

Kale, D., \& Little, S. (2007). From imitation to innovation: the evolution of R\&D capabilities and learning processes in the Indian pharmaceutical industry. Technology Analysis \& Strategic Management, 19(5), 589-609.

Kapur, D., \& Ramamurti, R. (2001). India's emerging competitive advantage in services. Academy of Management Perspectives, 15(2), 20-33. 
Karna, A., Upadhyayula, R., \& Kumar, V. (2014). Strategic archetypes of emerging market multinationals: analysis of uutward FDI of Indian firms. Advances in International Management, 27, 325-347.

Kathuria, V., Raj, S., \& Sen, K. (2013). Impact of human capital on manufacturing productivity growth in India. In N. Siddharthan \& K. Narayanan (Eds.), Human capital and development: the Indian experience (2nd ed., pp. 23-37). New Delhi: Springer.

Khanna, T., \& Palepu, K. G. (2010). Winning in emerging markets: a road map for strategy and execution. Boston: Harvard Business Press.

Khanna, T., \& Rivkin, J. (2001). Estimating the performance of business groups in emerging markets. Strategic Management Journal, 22(1), 45-74.

Knight, G. A., \& Cavusgil, S. T. (2005). A taxonomy of born-global firms. Management International Review, 45(1), 15-35.

Knowledge at Wharton (2010). Narayana Hrudayalaya: a model for accessible, affordable health care? http://knowledge.wharton.upenn.edu/article/narayana-hrudayalaya-a-model-for-accessibleaffordable-health-care/. Accessed 1 July 2010.

Knowledge at Wharton (2012). India continues to attract multinationals' research dollars. http:// knowledge.wharton.upenn.edu/article/india-continues-to-attract-multinationals-research-dollars/. Accessed 04 Oct 2012.

Krishnan, U. (2014). Watch where you spit: how India labor laws strangle growth: jobs. Bloomberg News. http://www.bloomberg.com/news/2014-08-13/watch-where-you-spit-how-india-labor-laws-stranglegrowth-jobs.html. Accessed 14 Aug 2014

Kumar, N., \& Puranam, P. (2012). India inside: the emerging innovation challenge to the West. Boston: Harvard Business Press.

Lamin, A. (2013). The business group as an information resource: an investigation of business group affiliation in the Indian software services industry. Academy of Management Journal, 56(5), $1487-1509$.

Leblang, D. (2010). Familiarity breeds investment: diaspora networks and international investment. American Political Science Review, 104(3), 584-600.

Lorenzen, M., \& Mudambi, R. (2013). Clusters, connectivity and catch-up: Bollywood and Bangalore in the global economy. Journal of Economic Geography, 13(3), 501-534.

Luo, Y. (2003). Industrial dynamics and managerial networking in an emerging market: the case of China. Strategic Management Journal, 24(13), 1315-1327.

Luo, Y., \& Tung, R. L. (2007). International expansion of emerging market enterprises: a springboard perspective. Journal of International Business Studies, 38(4), 481-498.

Motohashi, K. (2014). India as a destination of multinational's R\&D: growing importance and management strategy of local R\&D centers. Munich Personal RePEc Archive. February.

Mueller, J. M. (2007). The tiger awakens: the tumultuous transformation of India's patent system and the rise of Indian pharmaceutical innovation. University of Pittsburgh Law Review, 68(3), 491-641.

Nielsen, K. B., \& Waldrop, A. (2014). Women, gender and everyday social transformation in India. London: Anthem Press.

Oettl, A., \& Agrawal, A. (2008). International labor mobility and knowledge flow externalities. Journal of International Business Studies, 39(8), 1242-1260.

Philip, L., \& Vijayraghavan, K. (2011). Mahindra \& Mahindra hiring managers from overseas. Economic Times. http://articles.economictimes.indiatimes.com/2011-01-24/news/28426396_1_hemant-luthram-m-mahindra-mahindra. Accessed 24 Jan 2011.

Porter, M. E., \& Kramer, M. R. (2011). Creating shared value. Harvard Business Review, 89(1/2), 62-77.

Saxenian, A. (2005). From brain drain to brain circulation: transnational communities and regional upgrading in India and China. Studies in Comparative International Development, 40(2), 35-61.

Schmidt, E. (2013). The next five hundred million. In C. Chandler \& A. Zainulbhai (Eds.), Reimagining India: unlocking the potential of Asia's next superpower. New York: Simon \& Schuster.

Serrasqueiro, Z., Nunes, P. M., \& da Silva, J. V. (2012). Are financing decisions of family-owned SMEs different? empirical evidence using panel data. Journal of Management \& Organization, 18(3), $363-382$.

Thapar, R. (2002). The Penguin history of early India: from the origins to AD 1300. London and New Delhi: Penguin Books.

The Economist (2011), "Diasporas: mapping migration", Nov 17th, The Economist online, http://www. economist.com/blogs/dailychart/2011/11/diasporas. Accessed 16 July 2014. 
Thoppil, D. (2014). India's flipkart raises $\$ 1$ billion in fresh funding: e-commerce company girds for competition with Amazon, an eBay-backed rival. Wall Street Journal. http://www.wsj.com/articles/ indias-flipkart-raises-1-billion-in-fresh-funding-1406641579. Accessed 29 July 2014.

Tseng, M. W., \& Cowen, M. D. (2013). India's and China's recent experience with reform and growth. International Monetary Fund.

UNCTADstat (2014). http://unctadstat.unctad.org/wds/TableViewer/tableView.aspx. Accessed 28 July 2014.

World Bank (2014). World development indicators. World Bank. http://data.worldbank.org/indicator/SL. TLF.TOTL.IN/countries?display=default.

Ye, M. (2014). Diasporas and foreign direct investment in China and India. Cambridge: Cambridge University Press.

Zaheer, S., Lamin, A., \& Subramani, M. (2009). Cluster capabilities or ethnic ties: location choices by foreign and domestic entrants in the services offshoring industry in India. Journal of International Business Studies, 40(6), 944-968.

Zattoni, A., Pedersen, T., \& Kumar, V. (2009). The performance of group-affiliated firms during institutional transition: a longitudinal study of Indian firms. Corporate Governance, 17(4), 510-523.

Zhang, M. (2013). India and ASEAN economies to become the next China for (manufacturing) foreign direct investment (FDI). International Business Times. http://www.ibtimes.com/india-aseaneconomies-become-next-china-manufacturing-foreign-direct-investment-fdi-1039684. Accessed 25 Jan 2013. 